\title{
SOURCES OF FRAGMENTS BY THE ICONOCLASTIC Patriarch John Grammaticus (837-843): LEONTIUS OF BYZANTIUM
}

\author{
VLADIMIR A. BARANOV \\ Novosibirsk State University of Architecture, Design and Arts, Novosibirsk \\ baranovv@academ.org
}

\begin{abstract}
This article analyzes two fragments by the last Iconoclastic Patriarch John Grammaticus (837-843). A number of parallels to the doctrine in the fragments have been identified, including Aristotle, Theodoret of Cyrrhus, Basil of Caesarea, and John Philoponus. It is proposed that the main source of the fragments was a passage from the Epilyseis or Solutions Proposed to the Arguments of Severus by Leontius of Byzantium.

KEYWORDS: John Grammaticus, naming, definition of substance, Aristotle, Leontius of Byzantium.

* This study was supported by the Russian Foundation for Basic Research, project No. 19o11-00778, "Leontius of Byzantium and Patristics."
\end{abstract}

A number of arguments were employed by both sides in the Iconoclastic Controversy, ranging from Scriptural arguments, appeal to tradition, and Christological arguments to epistemological arguments, which were especially pronounced in the second period, involving not only the issue of circumscription, but also unequivocal definition of things and their naming. However, despite the shift in emphasis after each argument was countered by the Iconophiles, all arguments of the Iconoclasts revolved around one main point - they claimed that the Iconophiles worshipped the wrong subject, while calling it "Christ" and inscribing His name on the icons. ${ }^{1}$

${ }^{1}$ Cf. the Christological dilemma from the Definition of Hiereia: "For he [the painter V.B.] has made an icon and called it 'Christ.' But 'Christ' is the name of both God and man, therefore the icon is also the icon of God and man, and therefore, he circumscribed, in a way which seemed fit to his thoughtlessness, the incircumscribable divinity by the $\Sigma \mathrm{XO} \Lambda \mathrm{H}$ Vol. 14. 1 (202O)

(C) Vladimir Baranov, 2020 www.nsu.ru/classics/schole DOI:10.25205/1995-4328-2020-14-1-278-292 
The Iconoclastic arguments of the second period can be reconstructed from the refutation by the Iconophiles, not only presenting the Iconoclastic side for polemical purposes, but also citing some fragments from Iconoclastic writings, including three fragments of the last Iconoclastic Patriarch John Grammaticus, from the anonymous refutation of his three fragments contained in the manuscript Scorialensis Y-II-7 (fols. 200-206v) edited by J. Gouillard and A. Evdokimova. ${ }^{2}$ Two fragments are of particular interest for understanding the authentic Iconoclastic epistemological argument:

It is impossible to characterise a concrete man by a concept unless by an explanation through words, by means of which one can comprehend and define each being. For the proper accidents of a concrete being by which it has been separated from those belonging to the same species and, in another manner, are joined with those [who belong to different species], do not contribute in any manner and in any aspect to the perception of sight. For one cannot derive one's race or mark one's country, the certain kind of profession one spends time in, the sort of company one keeps, and of the rest of the ways of conduct worthy of praise or blame except by means of words, whereas it is impossible to truly distinguish a certain individual by means of some images.

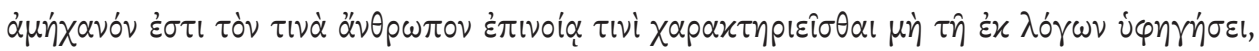

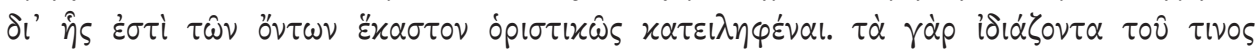

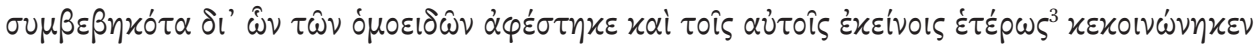

circumscription of the created flesh, or confused that unconfused union, falling into the lawless act of confusion" (ed. Lamberz 2016, 656.24-28). Cf. "The evil name of the falsely

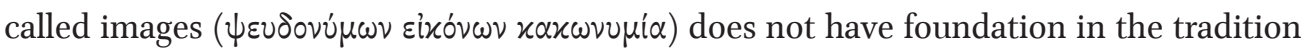
of Christ, nor of the Apostles nor of the Fathers" (Ibid., 676.15-16). See also Patriarch Nicephorus, Refutatio et inversio, 11 (ed. Featherstone 1997, 21.45), 66 (Ibid., 108.28), 67 (Ibid., 110.47), 16o (Ibid., 257.12); see also Lukhovitskij 2011.

${ }^{2}$ Three fragments were edited by Jean Gouillard (Gouillard 1966, 173-174). Alexandra Evdokimova edited the first Refutation, containing the first two fragments which were identified by Gouillard (Evdokimova, 2011-2012). Our first fragment (Gouillard's fragment No. 2) is cited according to the edition of A.A. Evdokimova; our second fragment (Gouillard's No. 3) is cited according to the edition by J. Gouillard. A brief biography of John Grammaticus can be found in Gero 1974-1975 and Katsiampoura 2010.

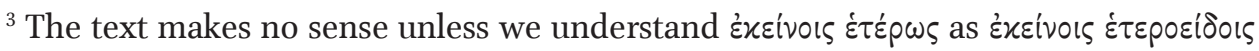
on the basis of one of the sources of this text - Leontius of Byzantium's Contra Nestorianos et Eutychianos 1, 4: "And one can discover that things of different species join in relationships with things of the same species in varying ways: for in the respects in which

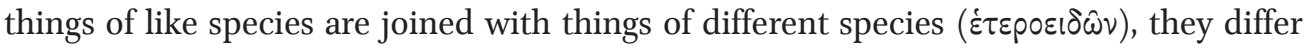
towards each other; and in the respects in which they differ from things of different species, they are joined to each other. For they are distinguished from each other but joined to things of other species by number, and they are joined to each other but distinguished from things of other species by definition (trans. Daley 2017, 145-147). 


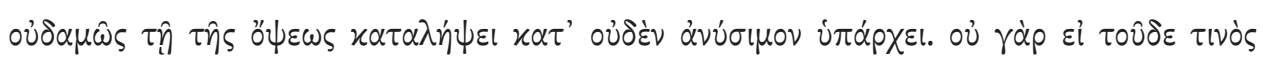

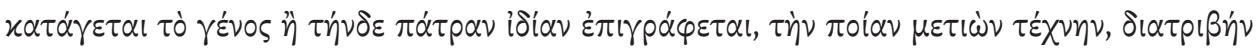

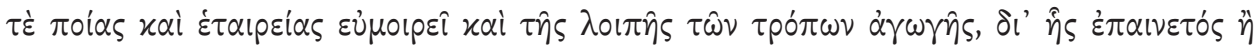

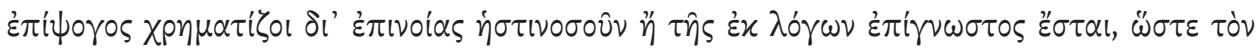

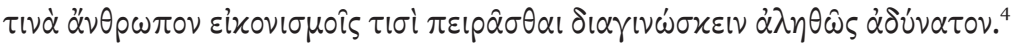

According to the argument of Patriarch John the Grammarian from this fragment, the precise and unique identification of a certain person within the same species can be provided only by means of words, a description which would separate one from other members of the same species on the basis of a unique set of his characteristics (as that person's place of origin, occupation, or way of conduct). Moreover, some visible characteristics which distinguish individuals from each other within the same species may coincide both for several individuals or even individuals belonging to different species (like color, shape, etc.), ${ }^{5}$ while the process of refinement or "sifting out" of a specific individual using his verbal descriptions can continue until the moment of final and complete identification. A verbal description is also convenient in that each time the set of context-creating characteristics can be different without affecting the accuracy of the result (that is, the apostle Peter can be characterized as "the apostle who renounced Christ three times", or as the "apostle who tried to walk on the waters and almost drowned because of his lack of faith"). With this identification, we avoid both erroneous identification and traps of homonymy. From John Grammaticus' point of view, identification of a person by means of his image is inefficient and therefore erroneous, resulting in total epistemological chaos, since looking at the image, one cannot be sure that this particular individual is depicted.

In the search for the sources of this doctrine, the famous passage from the Contra Eunomium II, 4 by Basil of Caesarea immediately comes to mind. ${ }^{6}$ In that text, Basil polemicizes with the difference in names designating differences in

${ }^{4}$ Evdokimova 2011-2012, 158; Gouillard 1966, 173-174.

${ }^{5} \mathrm{Cf}$. the passage from the Letter of the Three Patriarchs, whose doctrine seems to be criticised by John Grammaticus: "As the names are used for the copies and the prototypes, the copies display the personal features of the visible non-essential form

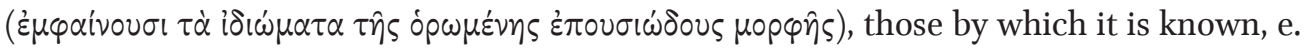
g. hookedness, greyness, whiteness or blackness or similar characteristic qualities; for the

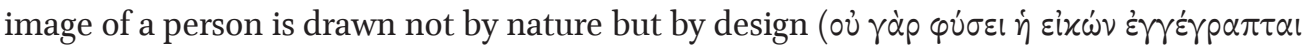
$\tau 0 \hat{\alpha} \nu \theta \rho \omega \dot{\omega} \pi 0 v, \dot{\alpha} \lambda \lambda \dot{\alpha} \theta \dot{\varepsilon} \sigma \varepsilon l) "$ (trans. Munitiz et al. 1997, 22; Greek text: Ibid., 23.1-5.

${ }^{6}$ As I earlier argued in Baranov 2007, 131-135. The same doctrine appears in Letter 38 of Basil of Caesarea, which in fact is the treatise of Gregory of Nyssa De differentia essentiae et hypostaseos ad Petrum fratrem (ed. Courtonne 1957, 81-83). On the authorship, see Zachhuber 2003, and Maspero et al. 2014. For a detailed analysis of the passage, see Kalligas 2002 and Biriukov 2016. 
substances, postulated by Eunomius, offering instead a contextual nature of naming revealing the qualities seen in an individual and his "distinctive character" rather than his substance. The context is defined by a number of descriptions which can be different inasmuch as they single out a unique individual:

Hence the designations do not signify the substances, but rather the distinctive features that characterize the individual. So whenever we hear "Peter," the name does not cause us to think of his substance - now by 'substance' I mean the material substrate which the name itself cannot ever signify - but rather the notion of the distinguishing marks that are considered in connection with him is impressed upon our mind. For as soon as we hear the sound of this designation, we immediately think of the son of Jonah, the man from Bethsaida, the brother of Andrew, the one summoned from the fishermen to the ministry of the apostolate, the one who because of the superiority of his faith was charged with the building up of the church. None of these is his substance, understood as subsistence. ${ }^{7}$

In addition to the common argument and denial of the role of name in referring to the "material substrate" which is indeed the only thing possible to be shown on the representation, the fragment of John Grammaticus and the passage of Basil have some parallels: the "race" of John Grammaticus corresponds to "the son of Jonah" from Basil's passage; "one's country" from the fragment to "the man from Bethsaida" from the passage; "the certain kind of profession one spends time with" from the fragment to "the one summoned from the fishermen to the ministry of the apostolate" from the passage; and "of the rest of the ways of conduct worthy of praise or blame" from the fragment to the "the one who because of the superiority of his faith was charged with the building up of the church" from the passage. $^{8}$

However, we may find a more immediate source of the fragment, if we consider it together with the following fragment of John Grammaticus, which shifts from an individual identification to a general identification on the level of species:

However, we cannot even simply and generally examine man, if we do not use the same method. ${ }^{9}$ For if man is defined as a rational mortal being, receptive of intellect and knowledge, how is it possible to entrust soulless and motionless things with [the task of] demonstrating the living motion, by which all that pertains to rationality has

${ }^{7}$ Trans. by DelCogliano and Radde-Gallwitz 2011, 134-135; Greek text: eds. Sesboüé et al. 1983 , vol. 2, 18.1-20.18.

${ }^{8}$ On the use of names in Basil's theology, see Robertson 2002 and DelCogliano 2010.

${ }^{9}$ The method of verbal definition, proposed by Patriarch John Grammaticus in the second fragment as the only means of precise definition of a being as opposed to its pictorial representation. 
been enabled to be as it is ${ }^{10}$ by God the Creator?! Thus, according to logic, the worshippers of the Word cannot call this colour-made monstrosity "mortal," nor can they say that it is receptive of any intellect and knowledge [...]

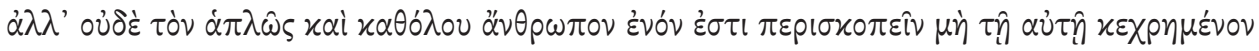

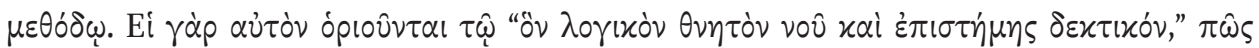

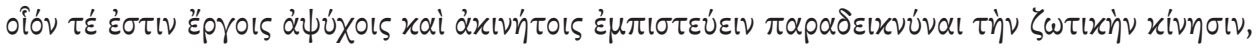

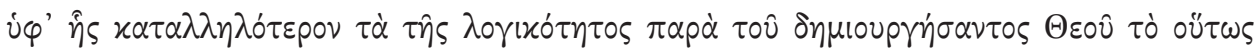

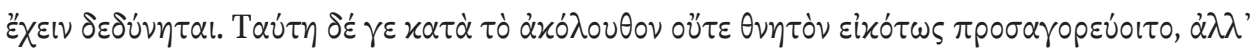

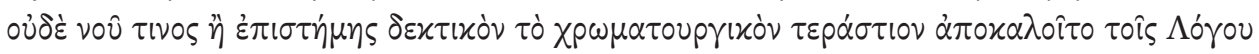

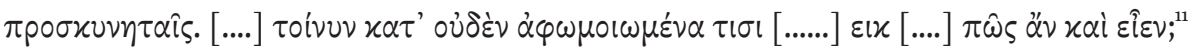

Patriarch John Grammaticus starts with a general definition of man on the basis of the Aristotelian definition of "a mortal living being receptive of intellect and knowledge ${ }^{\prime 12}$ and concludes that it is impossible to render the essence of the person by means of "motionless" images deprived of soul and intellect, and that icons as such are epistemologically fraudulent not only at the level of individuals but also at the level of species. Such an argument is based on the principle that a true image should convey the essential characteristics of the original or possess consubstantiality, which in the Iconoclastic doctrine corresponded to the Eucharist as a consubstantial "icon" of Christ. ${ }^{13}$ The fragment shows a doctrinal parallel to the passage from Theodoret of Cyrrhus, in his Questions on Octateuchus, where Theodoret explains what is that which was created in the image of God:

But also when man creates, he imitates in a certain way the Creator as an icon imitates the archetype. For the icon also has the traces of the archetype yet it only has the appearance of the members but does not have the activity for it is deprived of soul by which the body is moved.

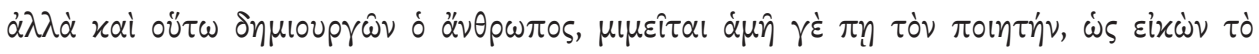

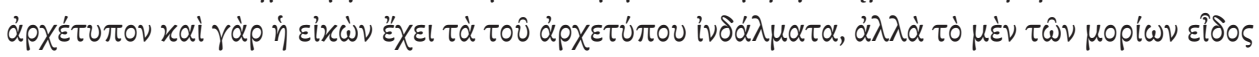

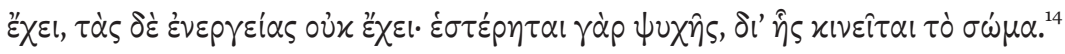

\footnotetext{
${ }^{10}$ Cf. Plato, Timaeus 3oab.
}

${ }^{11}$ Gouillard 1966, 174 .

${ }^{12} \mathrm{Cf}$. Aristotle's original definition: "An essential property is one which is assigned to something in contrast to everything else and sets a thing apart from everything else, for example, the property of man as 'a mortal living creature receptive of knowledge' ("E $\tau \tau$ เ

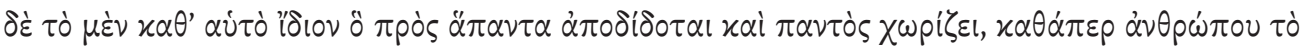

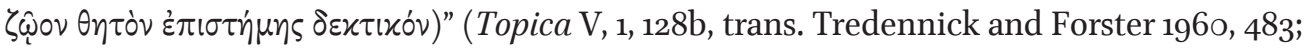

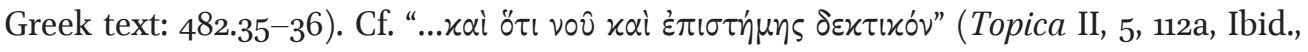
352.19).

${ }^{13}$ On the Iconoclastic Eucharistic doctrine, see Gero, 1975 and Baranov 2010.

${ }^{14}$ Eds. Fernandez-Marcos and Saenz-Badillos 1979, 26.1-4. 
As with the fragment of John Grammaticus, the passage from Theodoret states that an image only renders the external members of the person depicted, but falls short of rendering the person's essence because the image is "soulless" and "motionless," while the essence of the soul is defined by its ability to move the body. ${ }^{15}$ Besides the similarity in doctrine, the two passages also expose certain textual

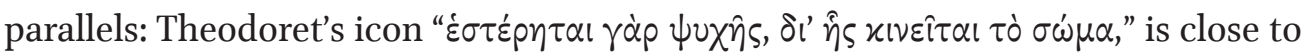

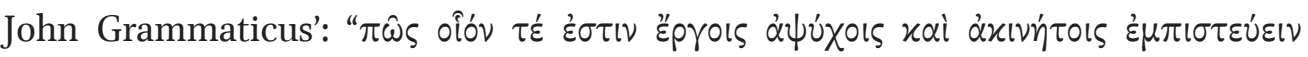

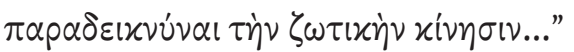

This passage of Theodoret of Cyrrhus on Genesis was not intended as a refutation of icons. The doctrine expressed there was a part of the general Antiochean line of anti-Apollinarian polemics, which emphasized the importance of the soul as the mover of the body. This passage depends upon the fragment on the same Biblical verses by Theodore of Mopsuestia (d. 416) preserved in catenae. ${ }^{16}$ Theodoret, however, provides an important development: he makes the qualification that the part within the domain of divine activities which was given to man as an imitation is the soul.

Theodoret here seems to respond to the doctrine of Apollinaris of Loadicea. In a fragment quoted in Justinian's Letter to the Monks of Alexandria (Contra Monophysitas), Apollinaris stated that a person can possess only one mover. This scheme must have derived from strict Aristotelian anthropology, where the composite of soul and body constitutes one perfect entity and the soul is the mover of the body. ${ }^{17}$ Perhaps in an ordinary person the soul moves the body, but the case seems to be more complicated with Christ: the Aristotelian scheme applied to the Christological union leads to the existence of two movers in Christ: the Word himself and Christ's human soul. Apollinaris solved the problem by eliminating

${ }^{15} \mathrm{Cf}$. another Iconophile response to this doctrine contained in the Letter of the Three Patriarchs: "If one spits upon His icon because it is inanimate and motionless, did not Christ too, after he donned his divine humanity, become without life, breath and motion, a corpse shut in a tomb? Are not the holy relics of the apostles, the martyrs and the saints lifeless and dead? Well, ought they then to be spat upon? Are not the bodies of those in cemeteries dead'? Is not the church building lifeless and an artefact assembled by human hands, which could be broken up again? Are not the God-inspired Gospels lifeless things and man-made?" (trans. Munitiz et al. 1997, 54; Greek text: 55.13-21). On the mediating function of the soul of Christ in the Iconoclastic doctrine, see Baranov and Lourie, 2009.

${ }^{16}$ Petit 1987, 280, fr. IX. On the notion of the image of God in man in the Antiochean tradition, see McLeod 1999.

${ }^{17}$ De Anima, 412ab, Hett 1986, 68-70. On the soul as the mover of the composite, see De Anima III, 9-11. In Christian sources, the soul of man was defined in terms of movement as early as Theophilos of Antioch (late second century), cf. Ad Autolycum, I, 5 (ed. Grant 1970, 6-7). 
one extra mover, namely, Christ's human soul and claiming that it was the Word who occupied the place of human intellect in Christ, thus, becoming himself the sole "mover" of Christ's body. ${ }^{18}$

In his response to Apollinarian anthropology, Theodoret stressed the importance of the soul as mover of the body and bearer of activity. However, if we look at the passage from a slightly different angle, what we have here is the essential foundation of the relation between the image and the archetype which was later used by the Iconoclasts: the icon is soulless and immovable since it has only external features of the archetype but not its essential qualities.

The writings of Theodoret, if indeed, a source for certain positions in the theology of the Iconoclasts, were not acknowledged by the Iconoclasts and do not appear in their florilegia. Most likely this is due to the fact that Theodoret could not be considered an authority because his Orthodoxy was challenged by the condemnation of several of his writings against St. Cyril of Alexandria at the Fifth Ecumenical Council. We have no indubitable proof that Theodoret was used by the Iconoclasts, besides the doctrinal similarity and a slight textual parallel in the fragment of Patriarch John Grammaticus. But we know that the commission which was headed by John Grammaticus (not yet Patriarch at the time) assembled the Patristic evidence for the Council of Saint Sophia in $815 .{ }^{19}$ Furthermore, John Grammaticus must have found a "stronger" fragment, which he believed to be by St. Basil of Caesarea. This fragment contained the same doctrine on the inadequacy of artificial images as compared to man as a perfect image of God in the interpretation of the same passage of the creation of man "in the image and likeness" that was in Theodoret - yet nobody could cast any doubts on the Orthodoxy of St. Basil of Caesarea. Thus, we read in the passage from St. Basil contained in the florilegium of the Council of Saint Sophia, assembled by the committee which included the future Iconoclastic Patriarch John Grammaticus:

If the power to become "in the likeness," were not granted to us, it would not have been in our own potency that we could acquire the likeness of God. But He made us similar to God by power: for He gave us the power to become similar to God; $\mathrm{He}$ made us able to work towards the likeness of God, when the benefit of our action is perfect. So that it would not be as on the images which come into being from an artist and remain purposeless and vain: for when you see [something] depicted accurately by a variety of colors, you do not praise the image but admire the artist.

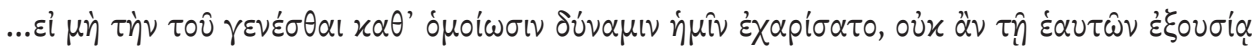

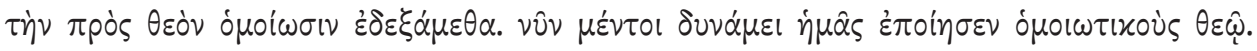

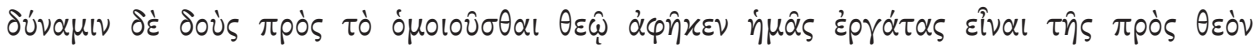

\footnotetext{
${ }^{18}$ See, for example, ed. Schwartz 1939, 17.1-5, No. 61.

${ }^{19}$ Alexander 1958, 126-128.
} 


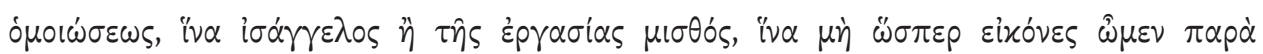

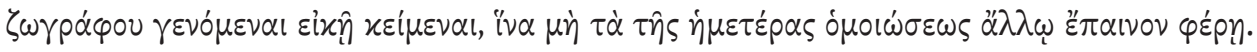

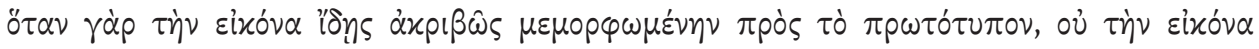

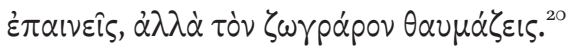

Why was the principle of strict correspondence of an image to the definition of substance and complete refusal of homonymy between substances so important to the Iconoclasts? In Metaphysics Z, 4-6 and 10-11, Aristotle explored substance as the essence of being ( $\tau \dot{0} \tau i \hat{\eta} \nu$ घival). Examining the definition of substance, Aristotle argued that "essence belongs to all things the account of which is a definition" (1030a4-5); such definitions are given to the "primary" species of a genus (and not derivative things such as artworks, giving an example of the Iliad). In determining the essence of being of something, we must first indicate its function, since the material substrate is not included into the definition of substance, but only into the whole. The soul is the substance and form of the body for animated beings. ${ }^{21}$ If we try to translate Aristotle's argument into the language of the Iconoclastic debate, the substance of man can be made known only by a logical definition as a "mortal living being receptive of intellect and knowledge." An image does not carry any part of this logical definition, but renders only the material component that is part of the composite, but not of the substance.

We may find a parallel to the curious expression "color-made monstrosity" ( $\tau$ ò

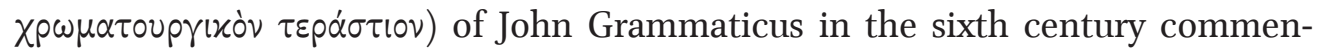
taries on Aristotle. Commenting upon Aristotle's Physics II, 192b8: "Of things which are, some are by nature and some through other causes," John Philoponus asks the question of how monsters appear, and gives the answer that in the case

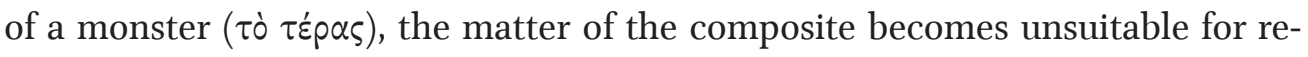
ceiving the proper form imposed by its logos of nature, but receiving an unnatural, "unorganised and indeterminate" form:

...suppose the surrounding atmosphere, mixed in such and such a way by the rotation of the heavenly [spheres], did something to the matter of a man in the process of generation so that he became unfitted to receive the form which nature would naturally impose upon him: then human nature would fail of its aim through the unsuitability of the matter, but another form would arise, which would be against nature in respect of the particular nature, but according to nature and by nature as regards the whole of nature - for nothing therein is against nature, since not even destruction is against nature, at any rate if generation is according to nature; and since generation is

\footnotetext{
${ }^{20}$ From Ps.-Basil of Caesarea, Homilia I de creatione hominis (ed. Hörner 1972, 30.131.3) =florilegium of the Council of Saint Sophia (ed. Featherstone 1997, 215.4-15).

${ }^{21}$ Metaphysica Z 10, $1035 \mathrm{~b} 15$.
} 
according to nature, destruction too will out of necessity be according to nature, assuming the generation of one thing is the destruction of another. ${ }^{22}$

Thus, applying the logic of John Philoponus to the fragment of John Grammaticus, in the case of the human being, the suitable matter of the body receives its natural form "imposed by" the soul, and all human beings correspond to the definition of substance homonymically bearing the name "man," common for the human species, while individual names are specific for each human hypostasis. The matter of the icon - wood and colors - lacks the human soul and is incapable of receiving the suitable natural human form from the soul, ${ }^{23}$ thus resulting in a "color-made monstrosity" having only the name but lacking the proper nature of whomever it intends to represent.

It is precisely in the Christological controversies of the sixth century that we may find the source of John Grammaticus' fragments. The role of constituent parts of the definition of substance in identifying beings belonging to the same species in the second fragment points to the figure of another polemicist of the sixth century, Leontius of Byzantium. The immediate source of both fragments of John Grammaticus very likely was the statement of the Orthodox concerning the characteristics of nature and hypostasis at the end of the dialogue with the Severian miaphysite, Epilyseis or the Solutions Proposed to the Arguments of Severus by Leontius of Byzantium, in a way summarizing and concluding the argument of the whole treatise:

For the characteristics which are admitted into the concept of the hypostasis mark off each individual from one another; but those admitted into the concept of the nature do not mark off the individual, but tell one kind of individual from another. The characteristics of the single individual, then, make it single: those which exist commonly are not predicated more properly of a general class, in any sense, than they are of the things of which they are generally said, even if they include all the individuals referred to under the same species.

And let us not forget this: the features which characterize the nature are constituent parts of its essence, while those which characterize a hypostasis belong, in a way, to the category of accidents, whether they are separable or inseparable. And in simple

${ }^{22}$ Trans. Lacey 1993, 16.18-29; Greek text: ed. Vitelli 1887, 201.19-27. I am grateful to Oleg Nogovitsyn, who pointed out this passage.

${ }^{23}$ Cf. the statement from the Iconoclastic Council of Hiereia: "He made His dwelling in the virginal womb, He assumed flesh consubstantial with us into his own existence or hypostasis from her holy and blameless flesh, and condensed and shaped it through the

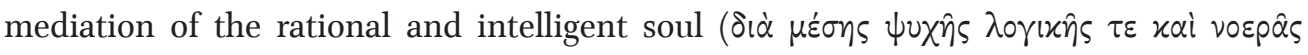

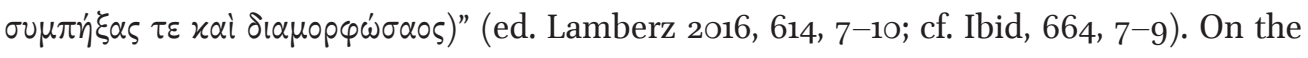
form-giving function of the soul of Christ in respect to his body, see Baranov 2011. 
beings, the characteristics of both [nature and hypostasis] are simple, while in conjoined and compound beings they are compound. This is how it is with the human person, and with the definition of him: animal, rational, mortal, capable of opposites by turns (for this is the surest definition of his essence) ) $^{24}$. All characterize his essence, while shape, color, size, time, place, parents, upbringing, way of life, and all that goes with them, characterize his hypostasis. The sum of them, they say, cannot hold true for anyone else, and nevertheless they belong to one man-namely, this one. And those marks properly belong to the characteristics of nature which exist in the same essence, while the characteristics of the hypostasis also include those which belong to different categories, when they are combined in the natural unity of an individual.

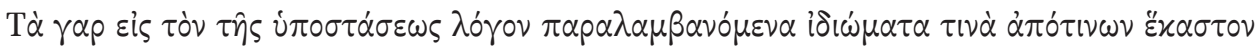

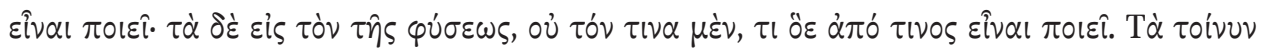

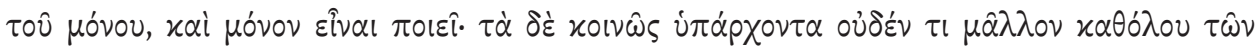

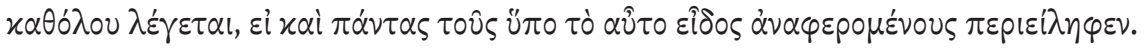

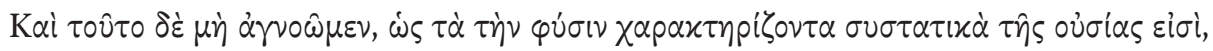

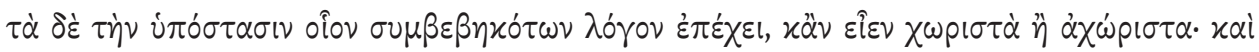

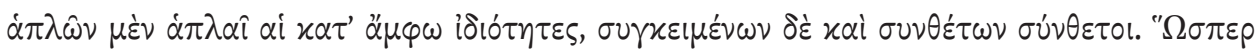

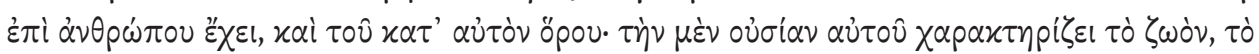

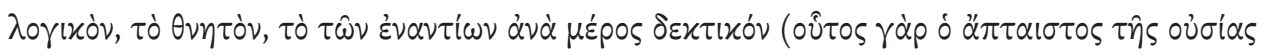

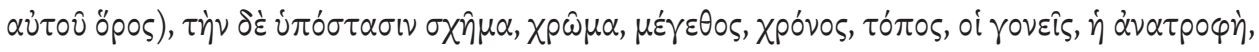

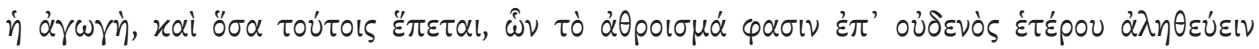

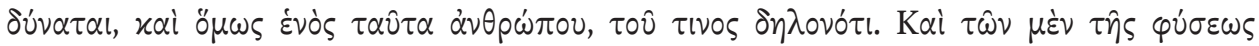

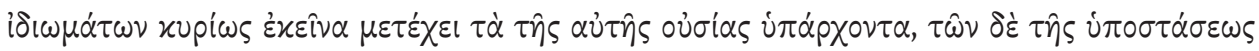

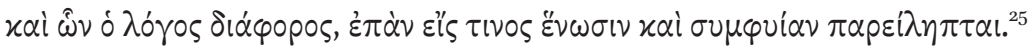

This passage contains all conceptual and verbal pieces of the fragments of John Grammaticus. Clearly, John Grammaticus excluded the properties of shape, color, size from the Leontius's enumeration of human characteristics, since it would concede to the Iconophile argument that their reproduction of the image safeguards its validity. ${ }^{26}$ Most importantly, the epistemological formulations of

\footnotetext{
${ }^{24}$ Leontius modifies here the Aristotelian definition (see supra, n. 13), and uses another modification of the definition: "flesh animated by a rational, intelligent soul" in the Triginta Capita (ed. Daley 2017, 322.14).

${ }^{25}$ Trans. Dailey 2017, 309; Greek text: 308.16-310.1; cf. Leontius of Byzantium, Contra Nestorianos et Eutychianos, Ibid., 134.3-13; on the use of the definition of being in Christological polemics, see Krausmüller 2011b, 492-493. On the Christological doctrine of Leontius, see Cross 2002, Krausmüller 2011b, Krausmüller 2014, Krausmüller 2017, Shchukin 2016, and Zhyrkova 2017.

${ }^{26}$ As, for example, does Patriarch Nicephorus in Antirrheticus I, 20 (PG 100, 244b), cf. Theodore the Studite, Antirrheticus III, 10 (PG 99, 393C). Nicephorus cites Leontius' Contra Nestorianos et Eutychianos 1, 3 in the Refutatio et inversio 61 (ed. Featherstone, 102.8103.22= ed. Daley 140.6-18) and uses Leontius' argument on the reversed nature of unions
} 
Leontius had been specifically tailored to Christological polemics, and the fragments of John Grammaticus were likely to have belonged to a Christological polemical treatise where the "anthropological epistemology" of the fragments was only a part of the wider dyophysite Christology of the Iconoclasts. ${ }^{27}$

Identification of the Christological epistemology of Leontius of Byzantium as a source of the Iconoclastic doctrine opens a new perspective on Iconoclastic Christology. The core of the Christological dilemma of the Iconoclasts that representing Christ on icons introduces either a mixture of the natures of Christ or their division, ${ }^{28}$ can be found in the treatise Contra Nestorianos et Eutychianos by Leontius of Byzantium who defends the Chalcedonian formula "one hypostasis of Christ in two natures" arguing that despite the seemingly opposite Christologies, both Nestorianism and Monophysiticm are based on one and the same failure of making a proper distinction between union according to substance and union according to the hypostasis. ${ }^{29}$ Leontius accuses two opposite heresies of one error; the Iconoclasts accuse the Iconophiles of two opposite heresies, possibly following the argument of Leontius in a reversed form. In addition, several puzzling doctrinal statements of the Council of Hiereia ${ }^{30}$ can also be logically placed within the conceptual framework elaborated by Leontius of Byzantium: in the Incarnation, the hypostasis of the Son and Word with divine substance and substantial divine properties, and with the inseparable hypostatic property of Sonhood has assumed enhypostasized human nature as an unqualified substrate in Leontius' sense $^{31}$ with only substantial human qualities understood in Aristotelian terms as "rational, mortal and receptive of intellect and knowledge," which safeguarded

and distinctions at the levels of theologia and economia in Antirrheticus I, 21 (PG 100, 248C, cf. Contra Nestorianos et Eutychianos 1, 1 ed. Daley 2017, 128.23-130.6).

${ }^{27}$ The Christocentric agenda was proclaimed by John Grammaticus in the introductory fragment (first fragment of Gouillard; ed. Evdokimova 2011-2012, 151-152).

${ }^{28}$ For the Christological dilemma in the definition of Hiereia, see ed. Lamberz 2016, 648.11-12, 650.4-5; 656.24-658.2; in the definition of St. Sophia, see ed. Featherstone 1997, $81,2-9$.

${ }^{29}$ Contra Nestorianos et Eutychianos 1, 1 (trans. Daley 2017, 128-131, Greek text: Ibid., 128.21-130.3).

${ }^{30}$ For example, "In the same way as that which He assumed from us is the mere mat-

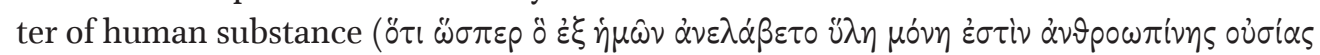

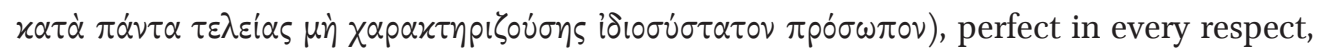
which, however, is not characterized as a person with a hypostasis of its own - in this way no addition of a person may occur in the Godhead - so did He command that the icon [the Eucharist - V.B.] also be matter as such" (ed. Lamberz 2016, 670.25-29).

${ }^{31}$ See Krausmüller 2011, 500-507 for the analysis of the notion of substrate in Leontius of Byzantium. 
the validity of the two natures of Christ. Therefore, according to the Iconoclasts, the hypostasis of Christ, as opposed to humans, could not be characterized by individualizing hypostatic qualities such as color, shape, and size, to avoid the "Nestorian" separate human hypostasis, and therefore it could not be circumscribed or depicted even according to his humanity. ${ }^{32}$ It should be mentioned that the Iconoclastic refusal to ascribe the characteristics of color, shape, and size to the hypostasis of the Word Incarnated did not mean Christ's colorlessness or shapelessness, but only that any such characteristics would be arbitrary and therefore epistemologically false.

Despite the fragmentary nature of John Grammaticus' writings, it is clear that he intended to build a coherent epistemological system, dwelling on a variety of sources. His knowledge of referential texts and concepts was promoted by his role of composer of the florilegium for the Council of St. Sophia in 815, and follows both the earlier Iconoclastic doctrine and the sixth-century Christological conceptual framework which radically modified the Cappadocian concepts of substance and hypostasis on the basis of Aristotle's doctrines. ${ }^{33}$

\section{REFERENCES}

Alexander, P. J. (1958) Patriarch Nicephorus of Constantinople: Ecclesiastical Policy and Image Worship in the Byzantine Empire. Oxford: Clarendon Press.

Baranov, V. A. (2011) "Condensing and Shaping the Flesh...': The Incarnation and the Instrumental Function of the Soul of Christ in the Iconoclastic Christology," S. Kaczmarek and H. Pietras, eds. Origeniana Decima: Origen as Writer. Bibliotheca Ephemeridum Theologicarum Lovaniensium 244. Leuven: Peeters, 919-932.

Baranov, V. A. (2007) "K voprosu ob ekzegeze svyatootecheskogo teksta po triadologicheskoj ptoblematike v ikonoborcheskikh sporakh" [Towards the problem of exegesis of Trinitarian texts in the Iconoclastic controversy], Sv. Troitsa prep. Andreya Rubleva $v$ svete pravoslavnogo apofatizma. 18 noyabrya 2005. Ikonoborchestvo: vchera i segodnya. 22 sentyabrya 2006. Materialy konferentsij [The Holy Trinity of St. Andrew Rublev in the light of Orthodox apophatism November 18, 2005. Iconoclasm yesterday and today. September 22, 2006. Conference proceedings]. Saint Petersburg: ID “Petropolis, 2007, 127-143.

${ }^{32}$ Cf. "For Leontius of Byzantium... human nature was given concrete existence through participation in the hypostatic idioms of the divine Word" (Krausmüller 2011b, 512). For more details on the Iconophile response to the Iconoclastic concept of "man in general ( $\delta$ x $\alpha \theta \dot{\partial} \lambda$ ov $\alpha \nu \theta \rho \omega \pi \circ \varsigma)$ " assumed by Christ in the Incarnation, see Theodore the Studite, Antirrheticus III, 15-23 (PG 99, 396D-401A).

${ }^{33}$ On the adaptation of the Aristotelian framework into Christological polemics of the sixth-early seventh centuries, see Krausmüller 2011a. 
Baranov, V. A. (2010) "The Doctrine of the Icon-Eucharist for the Byzantine Iconoclasts," J. Baun, A. Cameron, M. Edwards, and M. Vinzent, eds. Studia Patristica 44. Leuven: Peeters, 41-48.

Baranov V. A. and B. Lourie (2009) "The Role of Christ's Soul-Mediator in the Iconoclastic Christology," Gy. Heidl and R. Somos, eds. Origeniana Nona: Origen and the Religious Practice of His Time. Bibliotheca Ephemeridum Theologicarum Lovaniensium 228. Leuven: Peeters, 403-411.

Biriukov, D. (2016) "The Principle of Individuation in Contra Eunomium 2, 4 by Basil of Caesarea and Its Philosophical and Theological Context," Scrinium 12, 215-243.

Courtonne, Y., ed. (1957) Saint Basile. Lettres. Texte établi et traduit. Collection Budé. Vol. 1. Paris: Les Belles Lettres.

Cross, R. (2002) "Individual Natures in the Christology of Leontius of Byzantium," Journal of Early Christian Studies 10 (2), 245-265.

Daley, B. E., ed. and trans. (2017) Leontius of Byzantium: Complete Works. Oxford: Oxford University Press.

DelCogliano, M. (2010) Basil of Caesarea's Anti-Eunomian Theory of Names: Christian Theology and Late-Antique Philosophy in the Fourth Century Trinitarian Controversy, Supplements to Vigiliae Christianae 103. Leiden: Brill.

DelCogliano, M. and A. Radde-Gallwitz., trans. (2011) Basil of Caesarea. Against Eunomius. The Fathers of the Church 122. Washington, D.C.: The Catholic University of America Press.

Evdokimova, A. A. (2011-2012) "An Anonymous Treatise against the Iconoclastic Patriarch John the Grammarian. 1. The First Antirrhetic. The First Edition of the Manuscript Escorial Y-II-7, F. 200-205," Scrinium 7-8, 144-168.

Featherstone, J. M., ed. (1997) Nicephori Patriarchae Constantinoploitani Refutatio et eversio definitionis synodalis anni 815. Corpus Christianorum. Series Graeca 33. Turnhout/Leuven: Brepols/University Press.

Fernandez-Marcos, N. and A. Saenz-Badillos, eds. (1979) Theodoreti Cyrensis Quaestiones in Octateucum. Textos y Estudios "Cardenal Cisneros" 17. Madrid: Textos y Estudios "Cardenal Cisneros."

Gero, S. (1974-1975) "John the Grammarian, the Last Iconoclastic Patriarch of Constantinople. The Man and the Legend," Byzantina $3^{-4}, 25^{-35}$.

Gero, S. (1975) "The Eucharistic Doctrine of the Byzantine Iconoclasts and Its Sources," Byzantinische Zeitschrift 68, 4-22.

Gouillard, J. "Fragments inédits d'un antirrétique de Jean le Grammarien," Revue des études byzantines $24,171-181$.

Grant, R., ed. and trans. (1970) Theophilos of Antioch Ad Autolycum. Oxford: Clarendon Press.

Hett, W. S., trans. (1986) Aristotle, On the Soul. Parva Naturalia. On Breath. Vol. 8. Loeb Classical Library. Cambridge, MA: Harvard University Press.

Hörner, H., ed. (1972) De creatione hominis sermo primus, Gregorii Nysseni opera. Supplementum. Leiden: Brill. 
Kalligas, P. (2002) "Basil of Caesarea on the Semantics of Proper Names," K. Ierodiakonou, ed. Byzantine Philosophy and its Ancient Sources. Oxford: Clarendon Press, 31-48.

Katsiampoura, G. (2010) "John (Ioannis) VII the Grammarian: Scientist or/and Magician?" Archives internationales d'histoire des sciences 6o (164), 33-41.

Krausmüller, D. (2011a) "Aristotelianism and the Disintegration of the Late Antique Theological Discourse," J. W. Watt and J. Lössl, eds. Interpreting the Bible and Aristotle in Late Antiquity: The Alexandrian Commentary Tradition between Rome and Baghdad. Farnham: Ashgate, 151-164.

Krausmüller, D. (2014) "A Chalcedonian Conundrum: the Singularity of the Hypostasis of Christ," Scrinium 10, 371-391.

Krausmüller, D. (2017) "Enhypostaton: Being 'in Another' or Being 'with Another'? How Chalcedonian Theologians of the Sixth Century Defined the Ontological Status of Christ's Human Nature," Vigiliae Christianae 71, 433-448.

Krausmüller D. (2011b) "Making Sense of the Formula of Chalcedon: the Cappadocians and Aristotle in Leontius of Byzantium's Contra Nestorianos et Eutychianos," Vigiliae Christianae 65, 484-513.

Lacey, A. R., trans. (1993) Philoponus. On Aristotle Physics. Ancient Commentators on Aristotle. London: Duckworth.

Lamberz, E., ed. (2016) Concilium Universale Nicaenum Secundum. Acta Conciliorum Oecumenicorum. Series Secunda. Vol. 3. Pt. 3. Berlin/Boston: Walter De Gruyter.

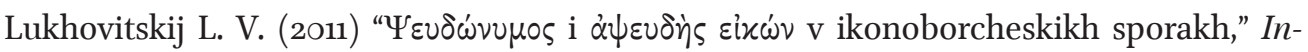
doevropejskoe yazykoznanie i klassichaskaya filologiya - XV. Materialy chtenij, posvyashchennykh pamyati professora Iosifa Moiseevicha Tronskogo 20-22 iyunya $2011 \mathrm{~g}$. [Indo-European linguistics and classical philology. Proceedings of the conference dedicated to Professor Iosif Tronskij, June 20-22, 2011]. Saint Petersburg: Nauka, 2011, 348-361.

Maspero G., M. Degli Espositi, and D. Benedetto (2014) "Who Wrote Basil's Epistula 38? A Possible Answer through Quantitative Analysis," J. Leemans and M. Cassin, eds. Gregory of Nyssa: Contra Eunomium III. An English Translation with Commentary and Supporting Studies (Proceedings of the 12th International Colloquium on Gregory of Nyssa (Leuven, 14-17 September 2010). Vigiliae Christianae, Supplements 124. Leiden: Brill, 579-594.

McLeod, F. G. (1999) The Image of God in the Antiochean Tradition. Washington, DC: The Catholic University of America Press.

Munitiz, J. A., E. Chrysostomides, E. Harvalia-Crook, and Ch. Dendrinos, eds. (1997) The Letter of the Three Patriarchs to Emperor Theophilos and Related Texts. Camberley, Surrey: Porphyrogenitis Ltd.

$P G=$ Migne, J.-P., ed. Patrologiae Cursus Completus. Series Graeca. Venice, 1857-1866.

Petit, F. 'L'homme créé 'à l'image' de Dieu. quelques fragments grecs inédits de Théodore de Mopsueste," Le Muséon 10o, 269-281. 
292 Sources of fragments by John Grammaticus

Robertson, D. G. (2002) "A Patristic Theory of Proper Names," Archiv für Geschichte der Philosophie 84, 10-19.

Schwartz, E., ed. (1939) Drei dogmatische Schrieften Justinians. Munich: Verlag der Bayerischen Akademie der Wissenschaften.

Sesboüé, B., G.-M. de Durand, and L. Doutreleau, eds. $(1982,1983)$ Basile de Césarée. Contra Eunome. 2 vols. Sources Chrétiennes 299 and 305. Paris: Cerf.

Shchukin, T. (2016) "Identity in Difference: Substance and Nature in Leontius of Byzantium's Writings," Scrinium 12, 308-321.

Tredennick, H. and E. S. Forster, trans. (1960) Aristotle: Posterior Analytics. Topica. Loeb Classical Library 391. Cambridge, MA: Harvard University Press.

Vitelli, H., ed. (1887) Ioannis Philoponi in Aristotelis Physicorum Libros Tres Priores Commentaria. Berlin: Reimer.

Zachhuber, J. (2003) "Nochmals: Der '38. Brief' des Basilius von Caesarea als Werk des Gregor von Nyssa," Zeitschrift für antikes Christentum 7(1), 73-9o.

Zhyrkova, A. (2017) "Leontius of Byzantium and the Concept of Enhypostaton: A Critical Re-evaluation, Forum Philosophicum 22 (2), 193-218. 